\title{
Vietnam and Threshold Conditions in the Process of Global Financial Integration
}

\author{
NGUYEN THI NGOC TRANG \\ University of Economics HCMC - trangtcdn@ueh.edu.vn \\ NGUYEN THI DIEM KIEU \\ Mobile World Joint Stock Company - kieunguyen.at@gmail.com
}

\section{ARTICLE INFO ABSTRACT}

Article history:

Received:

Apr. 012015

Received in revised form:

May 132015

Accepted:

Sep. 152015

Keywords:

Threshold conditions, financial integration, financial development, growth, institution, capital account liberalization.
The global financial crisis, once again, has ignited several intense debates over financial globalization merits, particularly for developing countries. There are probably a number of initial threshold conditions to be attained before substantial benefits may be reaped, and the risks of capital account liberalization, minimized. This article takes into account a series of empirical framework typifying these threshold conditions, estimating essential ones and accordingly proposing a few policy implications. Empirical evidence demonstrates that there exist specific thresholds in such variables with significant effects on the nexus between financial integration and growth, including those as clearly identifiable as financial depth and institutional quality. It is also shown by the findings that Vietnam's financial development has preliminarily satisfied the necessary conditions for efficient financial integration. In contrast, the institutional quality threshold remains far distant. 


\section{Introduction}

In recent years, especially after WTO accession, Vietnam has made a move toward greater integration into global market concerning both prescribed terms and the actual level of integration. Yet, the global financial crisis, once again, has ignited several intense debates over financial globalization merits and its impact on development of various economies, particularly developing ones.

Theoretically, the financial globalization is supposed to be facilitating efficient capital allocation and, in addition, international risk sharing; convincing empirical evidence, however, could not possibly be provided to include financial integration as a stimulant to economic growth and stability. There are seemingly a number of initial threshold conditions to be attained before substantial benefits may be reaped, and the risks of capital account liberalization, minimized. At present Vietnam, as an emerging economy, is obviously in a dilemma over whether or not and/or how to further condition the capital account liberalization. Does there exist a threshold level clearly pointing out economic features, which, if exceeded, will improve the trade-offs and make capital account openness more beneficial and less risky as for such a developing country? Subject to these vital issues, the purpose of this study is to: (i) define and estimate initial threshold conditions needed for positive effects resulting from the financial integration; and (ii) evaluate actual conditions in Vietnam in relation to necessary estimated thresholds, dependent on which, several policy implications are proposed.

\section{Theoretical bases}

Researchers in their earlier studies attempted to work toward comprehensive solutions to redress the balance between: (i) overwhelming theoretical prediction that financial integration may boost long-run growth in developing nations; and (ii) weak empirical realization of the theory. Kose et al. (2009) analyzed various debates in a framework and found that specific factors with effects on the financial integrationgrowth relation could be regarded as a set of threshold conditions. Figure 1 provides a description of such framework as well as lists several main threshold conditions, which encompass structural features of an economy like financial market development, institutional quality, trade integration, and macroeconomic policies. 


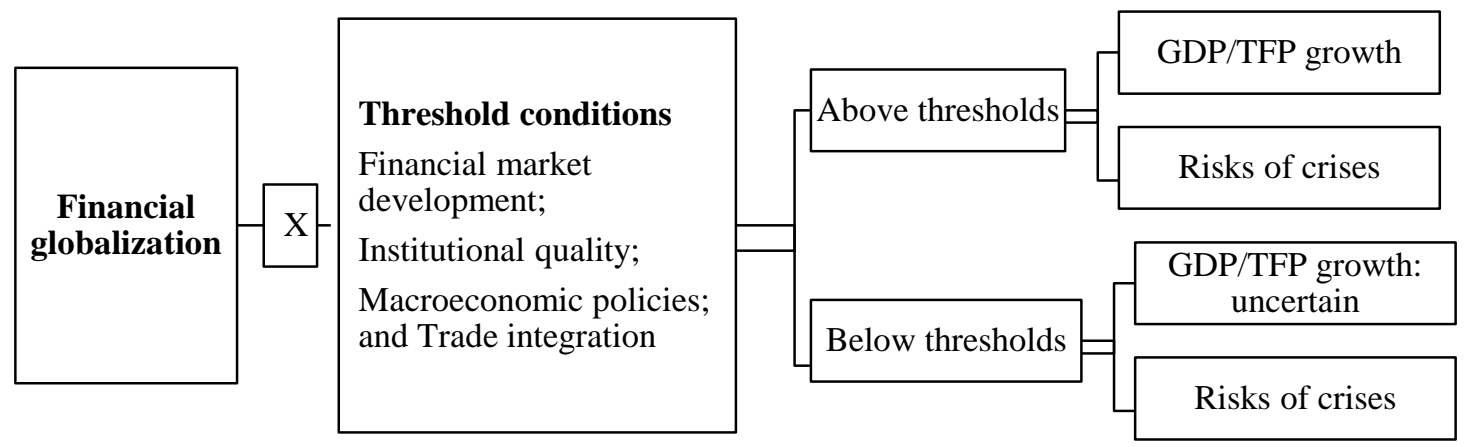

Figure 1. Threshold conditions in financial globlization

Source: Kose et al. (2009)

- Financial development: It has been theorized that financial development enhances growth benefits of financial globalization and mitigates vulnerability to crises. International and domestic financial limits play a crucial part in financially underdeveloped low-income economies, where certain restrictions are imposed on the access to arm's length financing on competitive terms. A few recent studies, from different theoretical approaches, have demonstrated that the interaction of these constraints may be conducive to possibly adverse and unpredictable effects of capital account liberalization. A change in capital flow direction may induce or exacerbate the boom and bust cycles in developing countries that lack deep financial sectors (Aghion \& Banerjee, 2005). Moreover, mismanaged domestic financial sector liberalizations have been a catalyst for crises relating to financial integration (Mishkin, 2006).

- Institutional quality: Quality of public administration and management, legal framework, corruption level, and the degree of government transparency may influence the allocation of resources in an economy, primarily - but not exclusively-the resources obtained from financial openness. Multiple studies point to conclusion that precursors of crises such as flawed macroeconomic and structural policies must have resulted from weak institutional quality (Acemoglu et al., 2003). Both Bekaert et al. (2005) and Chanda (2005) detected effects of interaction between institutional quality 
and financial liberalization on enhanced growth, while there was none according to Kraay (1998) and Quinn and Toyoda (2008). Klein (2005) found that merely intermediate levels of institutional quality would accompany a significantly positive impact of capital account openness on growth, hinting at the possibility of nonlinear threshold effects. Countries with better corporate and public governance receive more of their inflows in the form of FDI and portfolio equity, and clearly these are more stable than debt flows and also confer more of the indirect benefits of financial integration (Wei, 2001 as cited by Kose et al., 2011).

- Trade integration: Trade openness lowers the probability of crises relating to financial openness and mitigates the losses if any. As noted by Frankel \& Cavallo (2008), those economies with greater openness, which often need to adjust real exchange rate for the balance of current account, observe less severe effects of balance of payments thanks to devaluation and thus are less likely to be in default. This would also help these feel less pain caused by a sudden interruption of capital flows or avoid going through financial crises. Trade openness also contributes to an enconomy's better solvency and thereby its higher chance to escape recession.

- Macroeconomic policies: Greater success will be notched up with capital account liberalization providing it is supported by suitable fiscal, monetary, and exchange rate policies. Those which are limited or incompatible may accelerate risks of crises from an open capital account. Typically, a combination of fixed exchange rate and open capital account is one of the most common causes of monetary crises (Obstfeld \& Rogoff, 1995). Supervision of capital inflows, likewise, has arisen as a grave problem for an economy with huge fiscal deficits (Calvo et al., 2004).

Overall, there is evidence from theoretical and empirical research that provides a solid base for the existence of threshold conditions, albeit sparse and unable to give a clear description of the true nature of threshold relations or of how to translate conceptual into empirical framework in contracted form. In this study we focus merely on the analysis of growth effects as are revealed by financial globalization in its interaction with several threshold conditions. 


\section{Data and research methodology}

\subsection{Empirical model}

First, we empirically conduct growth regression with panel data of various countries over the time, focusing on long- and middle-run growth rather than other economic cycles and short-term fluctuations. Similar to previous studies, a five-year average of original data is employed.

A linear dynamic panel data model can be presented as follows:

$$
g_{i t}=\delta_{i}+\gamma_{t}+\theta x_{i t}+h\left(F O_{i t}, T H_{i t}\right)+\varepsilon_{i t}
$$

where $g_{i t}$ denotes the growth rate of real GDP per capita adjusted for PPP (a proxy for growth); $x_{i t}$ is a set of control variables of the growth model with coefficient of $\theta$; $\delta_{i}$, and $\gamma_{t}$ are country and time specific effects, respectively; $F O_{i t}$ represents financial openness; $T H_{i t}$ is threshold, and $\varepsilon_{i t}$ is residual.

One key issue is how to define the threshold relation in function of $\mathrm{h}\left(\mathrm{FO}_{\mathrm{it}}, \mathrm{TH}_{\mathrm{it}}\right)$. Based on earlier research, we consider three assumptions of the parameters measuring this function as below:

A high-low cut-off based on the sample median of a threshold variable:

$$
h\left(F O_{i t}, T H_{i t}\right)=\beta_{F O} F O_{i t}+\beta_{T H} T H_{i t}+\beta_{F O_{-} T H h i g h} F O_{i t} D\left(T H_{i}>T H_{\text {median }}\right)
$$

where $\mathrm{D}\left(T H_{i t}>T H_{\text {mediant }}\right)$ is an indicator (=1 if threshold of a country exceeds the median of all countries at the same time $t$ ). This method establishes exogenous threshold and offers a simple way to test whether the level of a certain variable is essential for financial openness impact on growth.

A linear interaction between financial openness and the threshold variable:

$$
h\left(F O_{i t}, T H_{i t}\right)=\beta_{F O} F O_{i t}+\beta_{T H} T H_{i t}+\beta_{F O_{-} T H} F O_{i t} T H_{i t}
$$

In its application to test how a certain variable produces linear effects on the marginal growth rate of financial integration, this technique implies that marginal impact (positive/negative) of financial openness on growth is larger at higher levels of the threshold variable.

A quadratic interaction allowing for nonlinear effects of the threshold variable:

$$
h\left(F O_{i t}, T H_{i t}\right)=\beta_{F O} F O_{i t}+\beta_{T H} T H_{i t}+\beta_{F O_{-} T H} F O_{i t} T H_{i t}+\beta_{F O_{-} T H s q} F O_{i t} T H_{i t}^{2}
$$


This enables a possibility that the threshold variable, when surpassing a specific level, becomes more or less significant in measuring marginal impact of financial openness on growth.

Estimates of growth regression functions in their short form customarily encounter a couple of problems concerning endogeneity and causality. A great surge in capital inflows, for example, into fast-growing economies can be experienced, leading to the dependence of financial integration on growth, but not the other way round. Likewise, financial development and growth may be affected by legal or other institutional frameworks, and "fixed" features of a country, correlated with explanatory variables. Evidently, it may be difficult for instrumental variables, completely exogenous, to be presented to cope with these issues, notably as with dynamism of a model and when the initial level of overall development is considered one control variable of the model (Kose et al., 2011).

Similar to earlier studies we use System Generalized Method of Moments (system GMM) for the panel data as developed by Arellana and Bond (1991) and Blundell and Bond (1998). Estimations perfomed via the system GMM work on a system including one differential equation for eliminating the fixed effects and one original equation. Appropriate lag value(s) of the original variables and corresponding difference(s) can then be used as instrumental variables (weak exogeneity) to attend to the problem of endogeneity. Furthermore, the system GMM is an estimator designed for situations with "small T, large N", meaning few time periods and many individuals (Roodman, 2006), which is highly consistent with a dataset of 85 countries and eight five-year averages. The application of two-stage technique, along with Windmeijer's adjustment process, is also important. In fact, the method is increasingly popular in relevant studies, as in Chang et al. (2009), who examined the nexus between institutional characteristics and trade openness, and Aghion et al. (2009), who investigated exchange rate regime in its interaction with financial growth. The present study, in addition, measures fixed effects (FE) with White's adjustment as a robustness check, whereas both the FE and system GMM do always include time effects in order to capture general determinants of growth among all the surveyed contries in the five-year period.

\subsection{Estimation and data}

We preferably use a simple estimator over complicated ones, and then conduct the robustness test for preliminary findings by means of alternative estimators. The dataset 
encompasses 85 countries during 1975-2013 for the maximum of eight non-overlapping five-year averages of all the countries. Still, due to data constraints, the final observation covers a four-year period between 2010 and 2013. To the same extent as in Kose et al. (2011), we exclude small countries (with population of less than one million persons) and others which offer limited statistics, especially on capital flows. A detailed description of all variables in the dataset is given in Table 1 below.

\section{Table 1}

Estimation and data sources

\begin{tabular}{|c|c|c|}
\hline Variable & Proxy & Source \\
\hline Growth & $\begin{array}{l}\text { Growth rate of real GDP per capita } \\
\text { adjusted for PPP }\end{array}$ & Penn World Tables \\
\hline \multirow{3}{*}{$\begin{array}{l}\text { Financial } \\
\text { integration }\end{array}$} & $\begin{array}{l}\text { Stocks of gross external assets and } \\
\text { liabilities to GDP }\end{array}$ & Lane and Milesi-Ferretti (2007) \\
\hline & Total external financial assets to GDP & Lane and Milesi-Ferretti (2007) \\
\hline & KAOPEN & Chinn \& Ito (2008) \\
\hline \multicolumn{3}{|c|}{ Threshold variables } \\
\hline \multirow{2}{*}{$\begin{array}{l}\text { Financial } \\
\text { development }\end{array}$} & Private credit to GDP & WDI \\
\hline & $\begin{array}{l}\text { Private credit and stock market } \\
\text { capitalization to GDP }\end{array}$ & WDI \\
\hline $\begin{array}{l}\text { Institutional } \\
\text { quality }\end{array}$ & $\begin{array}{l}\text { Worldwide Governance Indicators } \\
\text { (WGI) }\end{array}$ & WB \\
\hline $\begin{array}{l}\text { Trade } \\
\text { integration }\end{array}$ & $\begin{array}{l}\text { Total value of imports of goods and } \\
\text { services to GDP }\end{array}$ & WDI \\
\hline \multirow{2}{*}{ Macro policie } & CPI inflation per year & IFS \\
\hline & Government revenue and expenditure & IMF World Economic Outlook \\
\hline
\end{tabular}

Control variables 


\begin{tabular}{|c|c|c|}
\hline Variable & Proxy & Source \\
\hline $\begin{array}{l}\text { Initial level of } \\
\text { overall } \\
\text { development }\end{array}$ & $\begin{array}{l}\text { Initial per capita GDP at the beginning } \\
\text { of each five-year period measure }\end{array}$ & Penn World Tables \\
\hline \multirow[t]{2}{*}{$\begin{array}{l}\text { Level of } \\
\text { investment }\end{array}$} & Investment share of GDP & Penn World Tables \\
\hline & Population growth & WDI \\
\hline Human capital & $\begin{array}{l}\text { Average years of schooling in the } \\
\text { population over } 25 \text { years of age }\end{array}$ & Barro and Lee (2001) \\
\hline Infrastructure & Logarithm of telephone lines per capita & WDI \\
\hline
\end{tabular}

\section{Estimated results}

Since earlier studies highlighted the relation between financial openness and growth, we focus on the analysis of financial depth as a variable of threshold to illustrate the analytical framework of the research. The remaining thresholds are presented in the next section using similar framework.

Threshold conditions necessary for efficient financial integration

The regression results herewith are presented on the basis of five-year averages of the data. Empirical analyses begin with a limited set of control variables, referred to in previous research as relatively important factors affecting long-term growth in GDP per capita, including the natural logarithm of initial income (at the beginning of each fiveyear period), ratio of investment to GDP, a proxy for human capital (average years of schooling in the population over 25 years of age), and population growth. The results of basic growth regression using these control variables are presented in [1] of Table 2. Along with the system GMM, we employ the second lag as an instrumental variable, and the Arellano-Bond test in all estimations supports the hypothesis that no quadratic autocorrelation occurs. Regarding the Hansen test, the hypothesis that exogenous instrumental variables and the applied model are suitable is also supported, even at the $25 \%$ significance level as has been proposed by Roodman (2006). 


\subsection{Financial depth}

\subsubsection{Estimation techniques}

In Panel [2] of Table 2 we consider a wide measure of real financial depth, i.e. stocks of gross external assets and liabilities. The correlation between financial integration and growth is found, as is common in the literature, to be weak or even negative, which marks the discrepancy between theories and empirical evidence of the financial integration as well as its impact on growth.

In Panel [3] of Table 2 we are aware of whether any difference arises from the correlation between financial openness and growth among the countries with high and low levels of financial depth (proxied by ratio of private credit to GDP). The high or low levels are set by the median of financial depth according to each separate term. The results indicate that there exists a striking diference. As with the interaction of financial integration with high degree of financial depth, the coefficient on the interaction term is highly positive in the system GMM regression, and is nearly similar in magnitude to the negative coefficient on the financial openness. In other words, the impact of financial openness is of no plausibility as for an economy with a fairly low level of financial depth, and it is relatively good in the event of higher levels.

In Panel [4] of Table 2 we examine the linear interaction between domestic financial depth and financial openness. Given both FE and system GMM estimates, coefficients of financial depth and interaction variables are not statistically significant.

In Panel [5] of Table 2 we add to the study an interaction between financial openness and square of financial depth. Coefficients of interaction variables, given both linear and quadratic interactions, are, to this extent, highly significant in both FE and system GMM estimators, along the positive coefficients of linear interactions and negative coefficients of quadratic interactions for the two cases.

This shows that increased financial depth may result in an improvement in financial integration impact on growth but merely to a certain level of financial depth. The overall financial openness coefficient in this case follows an inverted U-shape when there is a rise in the threshold variable. Thus, we can estimate the cutoffs at which its sign changes and take account of the FE estimator and level of below threshold, under which there is a negative marginal impact of financial openness on growth, corresponding to the credit/GDP ratio of 69\%. Above this level the coefficients are positive, before becoming negative, for the credit/GDP ratio of over $165 \%$. Based on system GMM results, the 
corresponding threshold level is the credit/GDP ratio ranging from $75 \%$ to $170 \%$. Just for illustration the median levels of the credit/GDP ratio for industrialized countries (ICs), emerging economies (EMs), and other developing countries (ODCs) are 84\%, $42 \%$, and $21 \%$ respectively.

For both the estimators most observations reveal that the number of ODCs that are under the below thresholds and have negative coefficients of overall financial openness reaches about $90 \%$, whereas this figures for EMs and ICs are 76\% and 35\% respectively (compared to threshold levels based on the system GMM estimator). Proportion of observations is midway between upper and lower thresholds, financial openness coefficients are positive, being $60 \%$ and $24 \%$ for ICs and EMs respectively. In the next discussion we stress the lower thresholds, which are more relevant to EMs and ODCs ${ }^{2}$.

\subsubsection{Sensitivity of financial depth threshold}

The sensitivity of the results for the financial depth threshold can be tested in a few ways: First, we employ a different set of control variables and repeat the regressions in Table 2. Besides the retention of log initial income, education, and population growth, we add the variables such as trade openness, CPI inflation, and logarithm of number of phone lines per capita, which proxies for the level of infrastructure). The results in Panel [1] of Table 3 show highly similar signs and magnitudes of the coefficients of interest.

Next, as an alternative measure of financial depth, the ratio of sum of private credit and stock market capitalization to GDP is employed. The sample, regrettably, contracts to approximately half of the original size, subject to the absence of stock markets in many developing countries. Concerning the estimation with quadratic interactions, the results are statistically significant only in the system GMM estimator (see Panel [2] of Table 3). The lower and upper thresholds of the ratio of sum of private credit and stock market capitalization to GDP are 1.83 and 3.34 respectively (compared to the corresponding $77^{\text {th }}$ and $98^{\text {th }}$ percentiles respecting the private credit/GDP ratio in Table 2). Accordingly, for the system GMM estimation the results can be found to be rather similar to the basic ones in Table 2. 


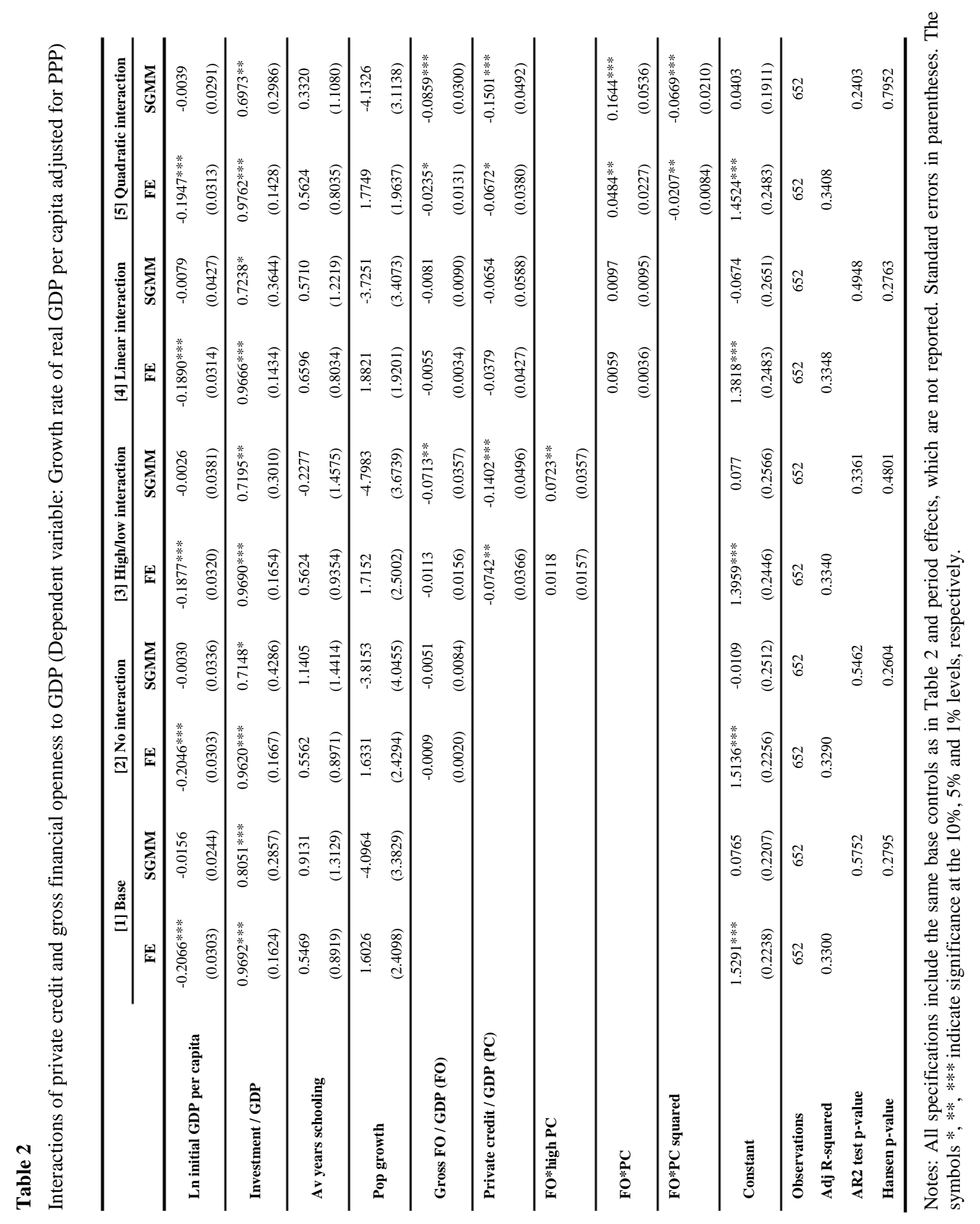




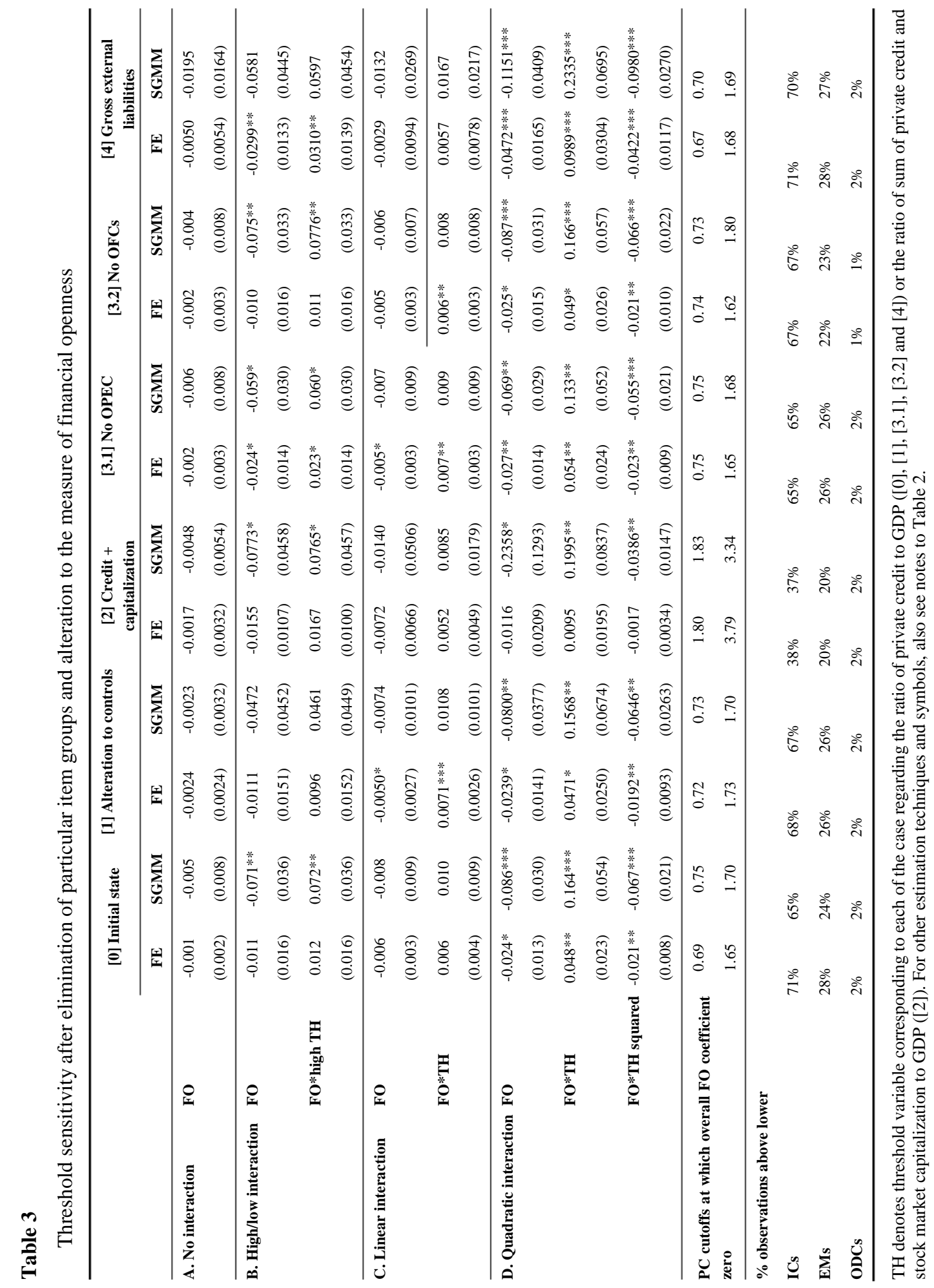


Then, a test for whether the results are affected by the choice of items in the sample is performed by removing at a time one of the two groups: (i) OPEC countries (Algeria, Ecuador, Indonesia, Iran, Kuwait, UAE, and Venezuela); and (ii) offshore financial centers (Ireland, Panama, and Singapore). Panels [3.1] and [3.2] show that signs and magnitudes of the coefficients, as well as the estimated thresholds, are quite stable during the elimination, implying our results are not fluctuated by certain groups of countries.

Last, in an attempt to return to its original state we examine an alternative measure of financial openness (FO) - ratio of stocks of external liabilities to GDP, which has some connection with emerging and developing economies. The results based on Panel [4] of Table 3 demonstrate that the threshold value of private credit to GDP does not undergo much change, as is compared to the baseline results.

\subsection{Other alternative thresholds}

This section contributes to the threshold effects revealed by a series of other indicators which were discussed in Section 2. While the FE and system GMM estimates are similar to what is reported in Table 2. Table 4 signifies different measures in the event that institutional quality serves as a threshold. In Panel [1] we attempt a composite measure of institutional quality (average of the six indexes proposed by WGI), which is also found to produce a clear threshold impact. Bearing certain similarity to financial depth, the institutional quality impact on financial integration is inverted U-shaped with the lower and upper thresholds of 0.38 and 1.73 respectively in the system GMM estimator. The number of ICs above the lower threshold is $99 \%$ (nearly the whole observed items), whereas the figures for EMs and ODCs are 27\% and 14\% respectively.

Going further, we visually look at some aspects concerning the institutional quality. Table 4's findings reflect that apart from political stability, the other factors reveal observable threshold effects. The highest threshold condition is attached to regulatory quality (a lower threshold of 0.5 according to the system GMM estimator), while voice and accountability indicator reaching 0.11 establishes the lowest rate of lower threshold condition. 


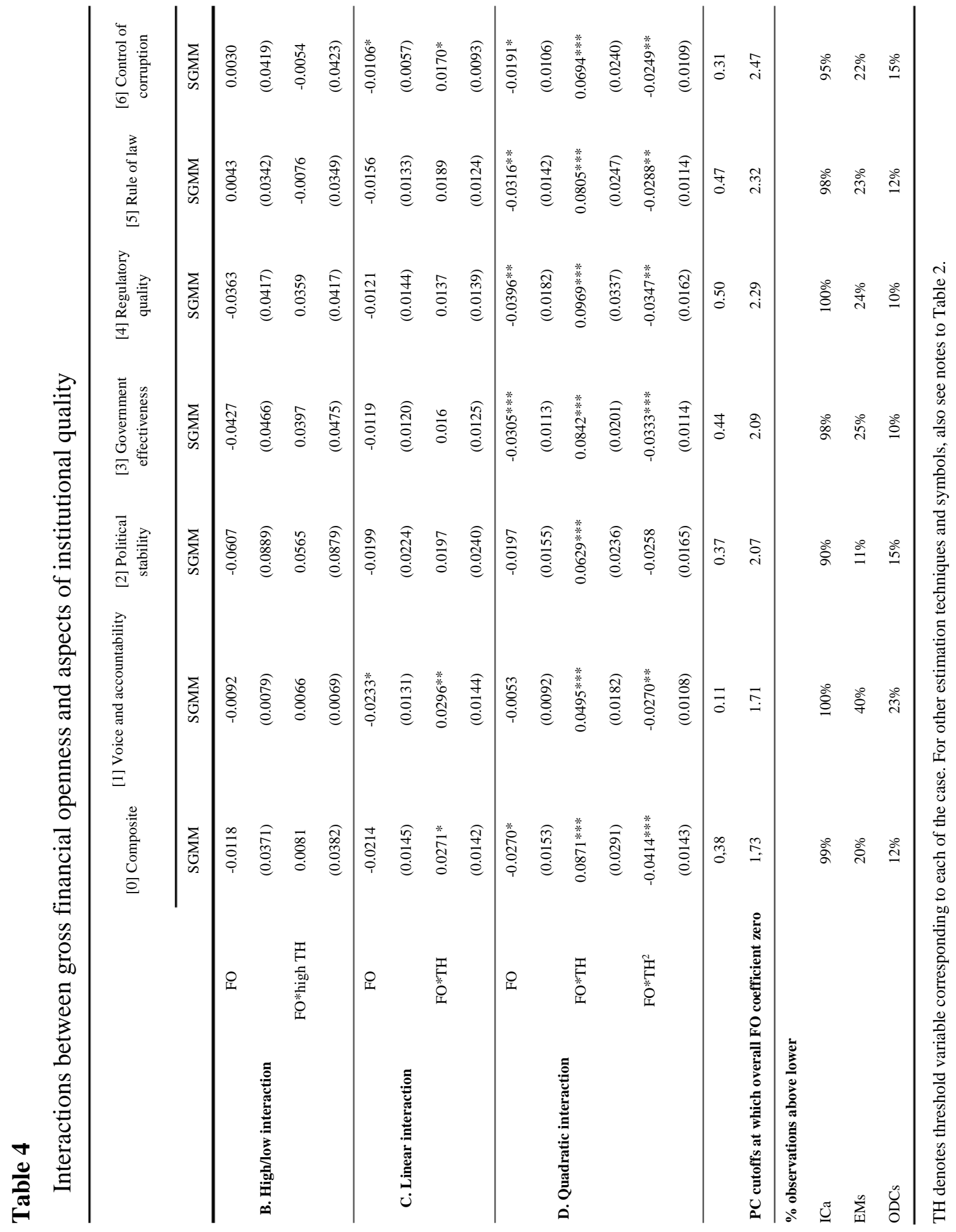


We also take into account trade openness (the ratio of the sum of imports and exports to GDP), macro policies (inflation volatility and the ratio of government revenues to expenditures), and level of income per capita — on the basis of international comparisons across countries, adjusted PPP, regarded as a proxy for a range of growth determinantsas threshold variables, even though most of the interaction coefficients are not statistically significant. When KAOPEN - a measure of de jure financial openness indicator - is viewed as a threshold variable, the relationship among de jure financial openness, real financial integration, and growth is inverted U-shaped, with the lower thresholds, in the FE and system GMM estimates, of 0.44 and 0.25 respectively (standardized KAOPEN ranging from 0 to 1 ). All the same, the estimated coefficients are not significant in the system GMM estimation.

To visually observe the estimated thresholds for important threshold variables, Figure 2 illustrates the measures of overall financial openness coefficient (including interactions) versus different values of the corresponding threshold variable (system GMM estimation). Private credit and institutional quality showcase inverted U-shaped relationships. With regard to financial depth threshold, point estimates of overall financial openness coefficient turn positive, corresponding to private credit as a ratio to GDP from $75 \%$ and larger than zero with significance level ranging from 83\%. As another threshold variable, the case of institutional quality reflects that the overall financial openness coefficient reverts to being positive from 0.38 and significantly positive from 0.54 . These results imply the existence of threshold effects on financial integration, at least as are hinted by financial depth and institutional quality variables. 


\section{Financial depth threshold}

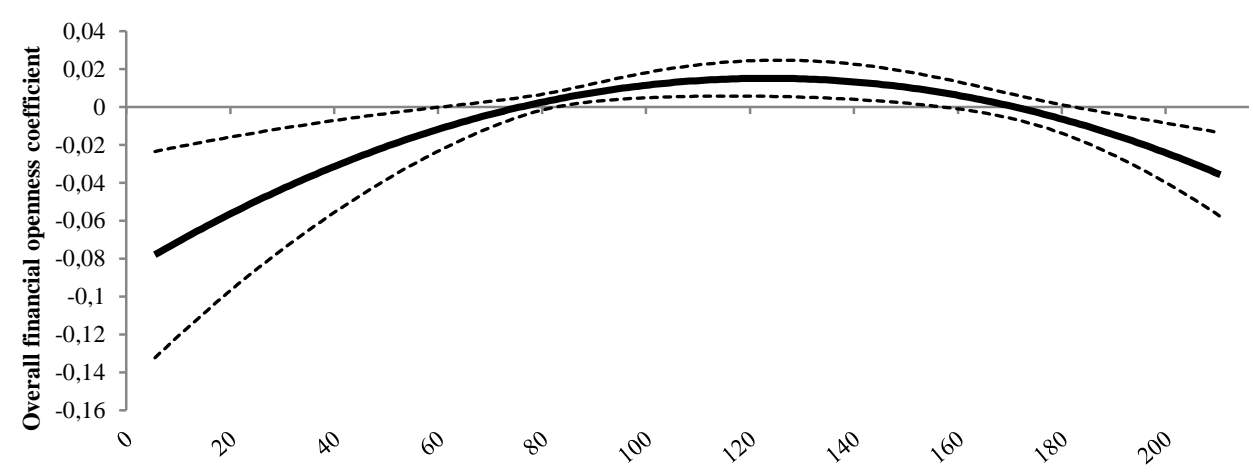

Private credit as a ratio to GDP $(\%)$

\section{Institutional quality threshold}

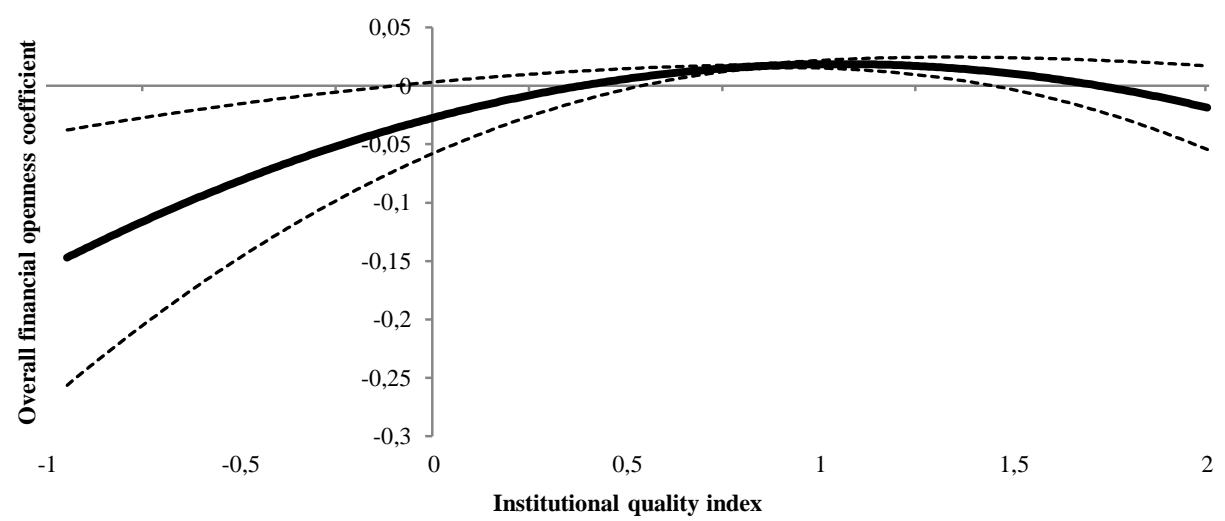

Figure 2. Effects of particular threshold variables on financial integration

Note: Upper and lower lines show confidence intervals of $95 \%$

\section{Evaluation of Vietnam's situation in connection with necessary thresholds}

To bring about the desired effects of financial integration on growth, it is important for countries to satisfy initial conditions, as proved by the research findings, concerning level of financial development and institutional quality. In Vietnam's circumstances the 2007-2008 period marks a significant milestone in the process of global financial 
integration in terms of both de jure and de factor integration (Figure 3). Should a post2007 leap in financial integration account for certain effectiveness, particularly under the profound impact exerted by financial crises on the world economy?

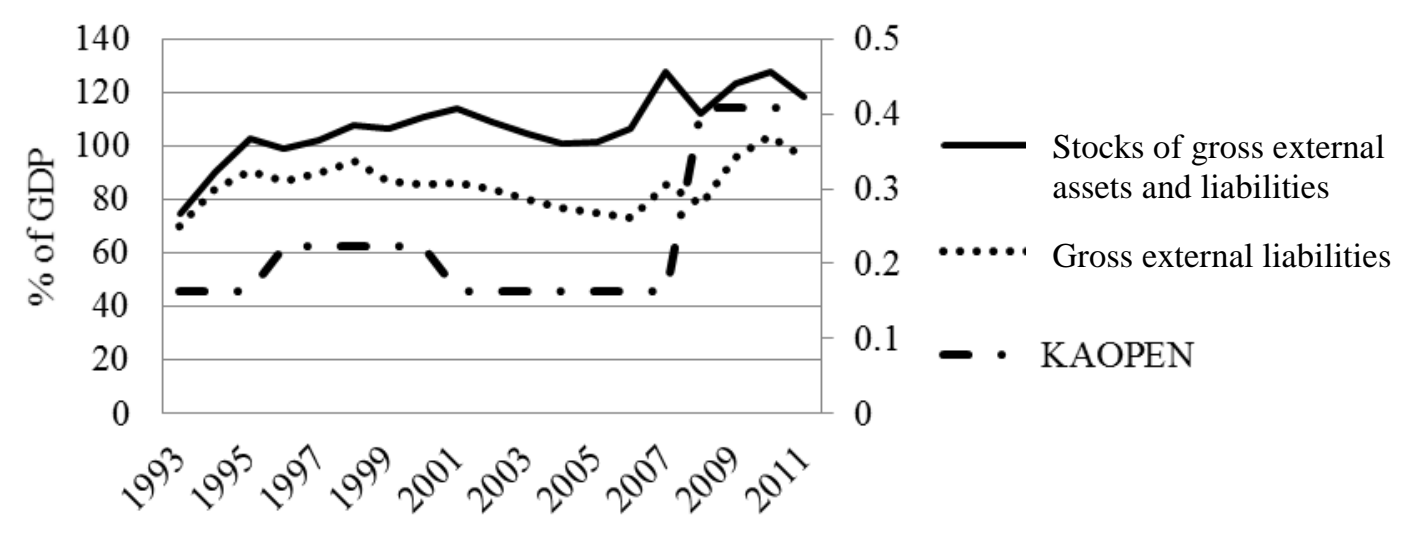

Figure 3. Level of Vietnam's financial openness

Source: Lane and Milesi-Ferretti (2007); Chinn and Ito (2008)

Figure 4 plots Vietnam's financial depth during 1993-2013 in correlation with necessary thresholds in system GMM estimation. In 2007 Vietnam's private credit as a ratio to GDP reached $85.6 \%$, being higher than the level of $75 \%$ as have been retained from the system GMM regression and high enough for the interaction coefficient for financial integration and growth to be significantly positive. Above this level the interaction coefficient for overall financial integration and growth helps magnify the effects of financial openness rising after 2007. However, the financial depth only exceeded the threshold needed; not only does it tend to be volatile but it has also dropped since 2011. If the incident lasts and the level of financial depth turns lower than has been set by the threshold, its effects will become increasingly negative due to the negative coefficient of overall financial openness. 


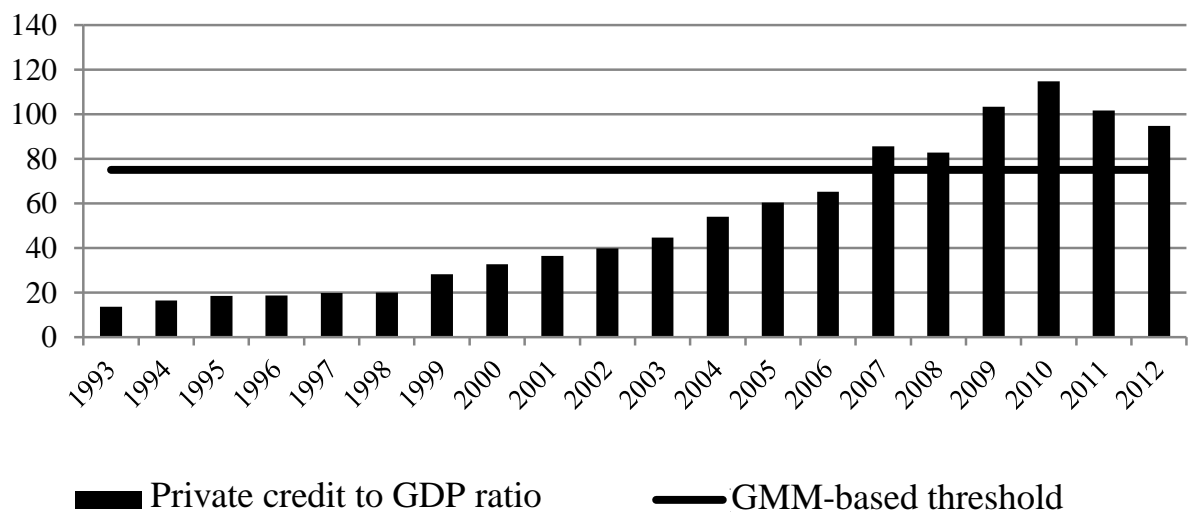

Figure 4. Vietnam's ratio of private credit to GDP and estimated threshold (\%) Source: WDI and calculations (Table 2)

In contrast, remaining distant from the required threshold level, the institutional quality index of Vietnam signified no tendency to improve (Figure 5): the indexes were -0.51 on average, compared to the threshold level of 0.38 as of 2007.

Considering different measures of institutional quality, Vietnam's index of political stability presented itself in the best manner. Also, despite its volatility, it is acceptable that the index have reached the required threshold level when compared to its own threshold ( 0.37 , abeit statistically insignificant). Still, there has been a decrease tendency displayed by the index since 2005 . 


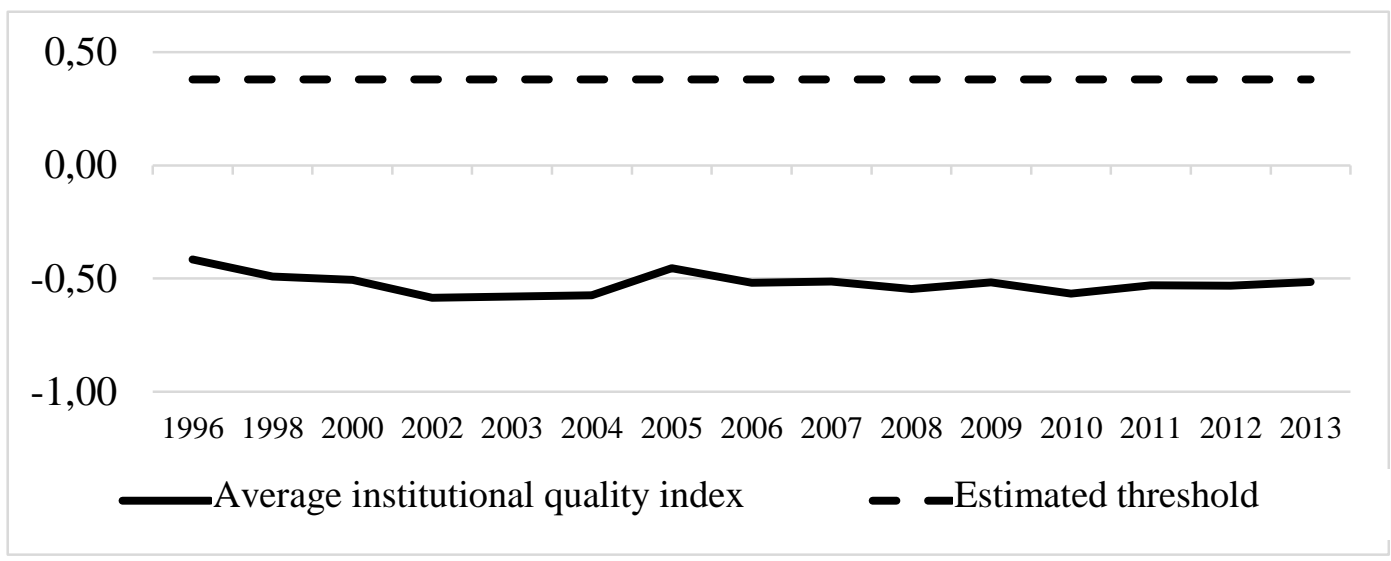

Figure 5. Institutional quality index of Vietnam on average and estimated threshold Source: WGI and calculations (Table 4)

Voice and accountability index ranged from zero to $10 \%$ globally, always at the lowest level of all Vietnam's indexes. It arrived at -1.5 points (compared to 0.11 as required) in 2007 and 1.3 points in 2013. Such low levels reflect clear reluctance of individuals and organizations during the survey on people's voice and government's accountability via such event as Decree No. 72/2013/ND-CP on the management, provision, and use of Internet services and online information. Lying far below the necessary thresholds, the remaining indexes, apart from control of corruption index, tend to fall (Figure 6). 

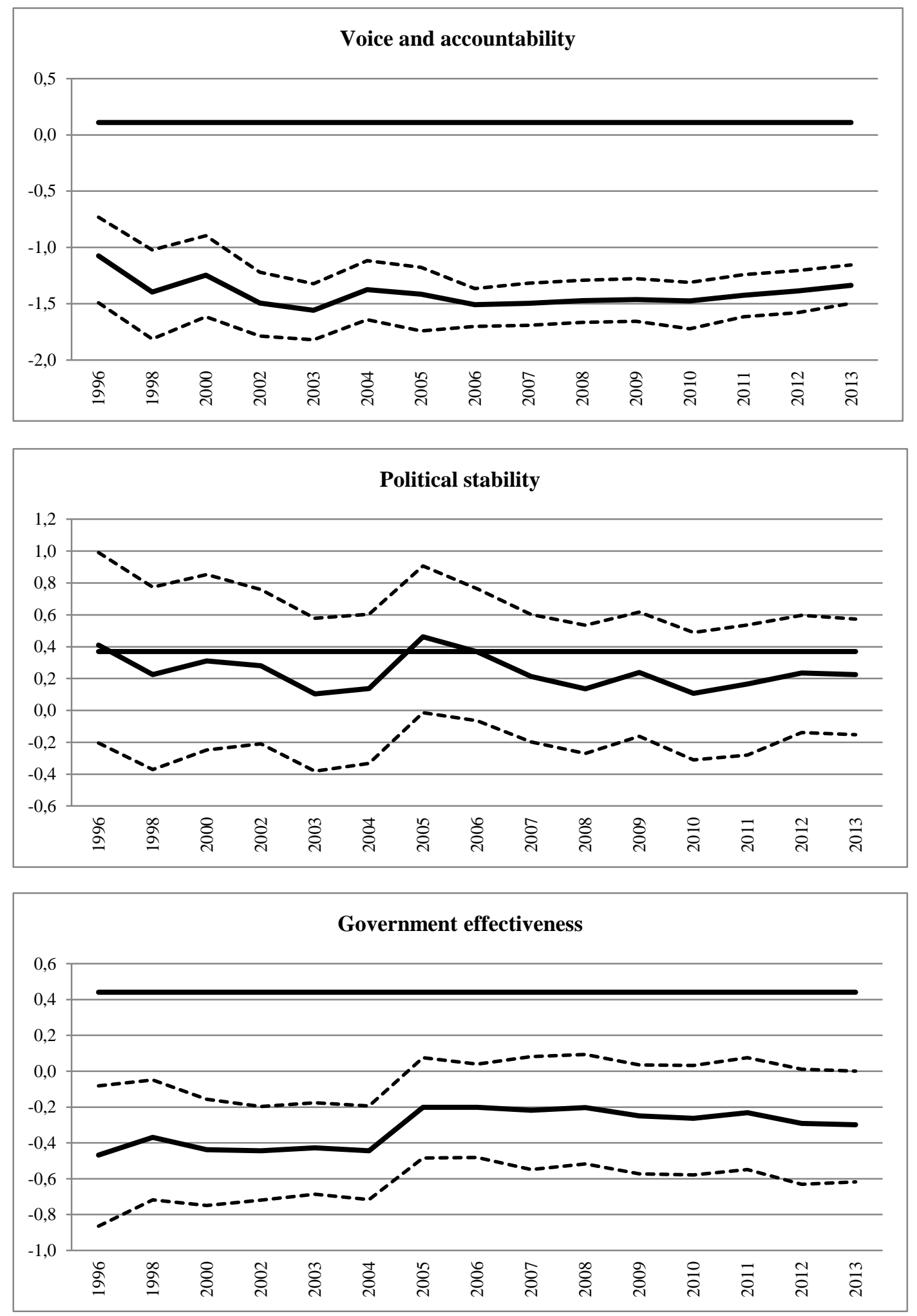

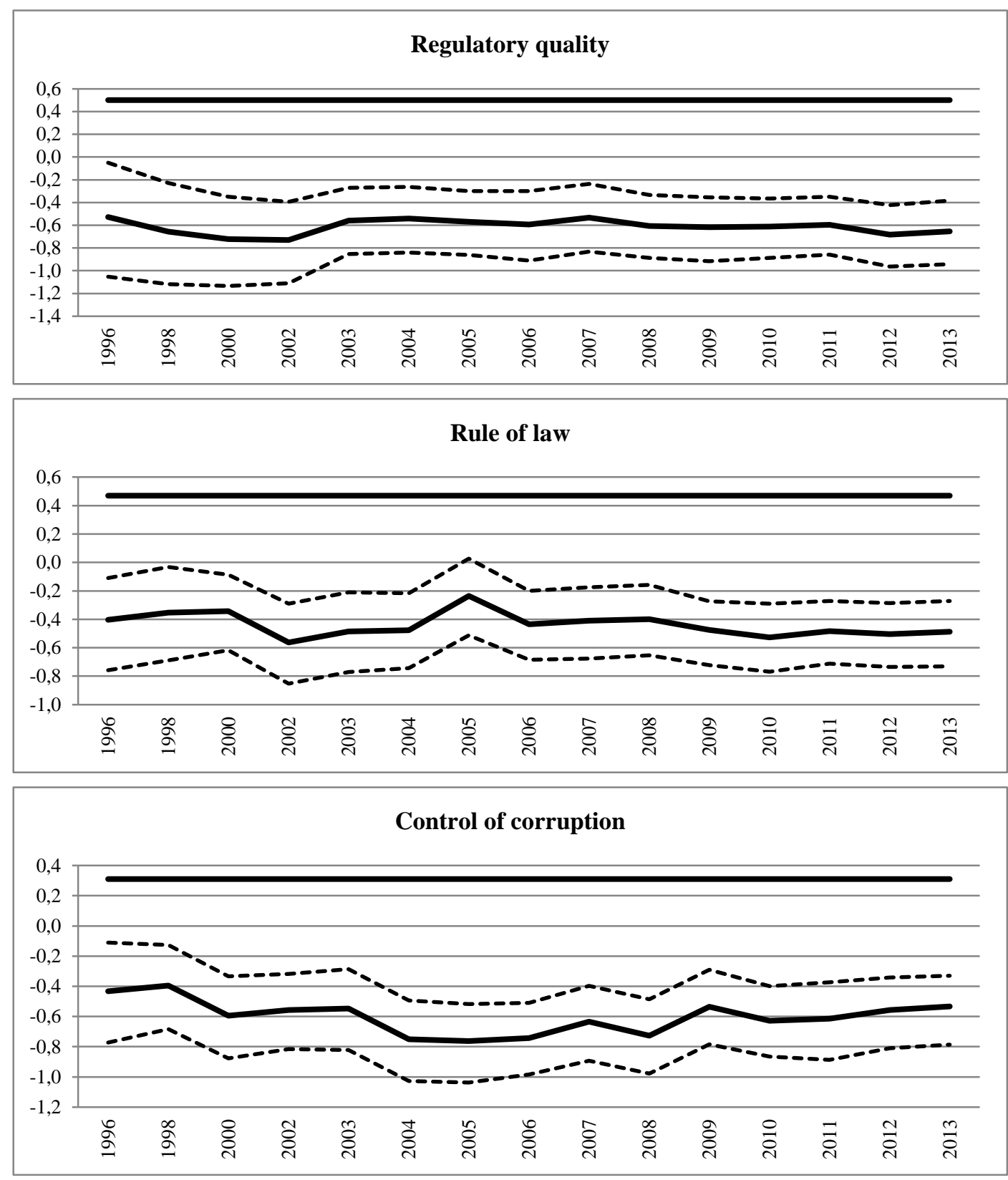

Note: The solid lines illustrate the estimated thresholds for corresponding indexes, and the dashed ones denote confidence intervals of $90 \%$ of corresponding indexes.

Figure 6. Measures of Vietnam's institutional quality and estimated thresholds Source: WGI and calculations (Table 4) 


\section{Conclusion and policy recommendations}

\subsection{Conclusion}

Based on Kose et al. (2011), the study investigates a few empirical structures with regard to threshold conditions, dependent on which several recommendations are further proposed. Its findings articulate the existence of threshold levels as were reflected by particular variables, notably, financial depth and institutional quality, which importantly drive the financial integration-growth nexus. Though stability is lacked, the level of Vietnam's financial development has preliminarily satisfied the threshold conditions essential to effective integration. On the contrary, its institutional quality indexes remain lower than the levels required and show a falling trend.

\subsection{Policy recommendations}

The analyses point out real benefits from financial integration. Financial development reaching a required threshold could either mitigate risks or turn negative due to deficiencies in institutional quality or managerial competence in connection with macro policies. In line with the outcomes four recommendations can be provided as follows:

- In short terms proceed with capital account liberalization partially rather than wholly until the institutional quality and financial development are considerably improved and enhanced: It is, however, imperative to focus on indirect measures, instead of administrative ones, of control over foreign capital flows. For instance, taxes shall be either heavily imposed on short-run speculative flows or available for FDI flows, which offer far more career opportunities without adverse effects on domestic business climates.

- Tightly control foreign debts, especially those suffered by the SOE sector via the issuance of international bonds: This implies no government's guarantees for SOEs' debts.

- In the context of controlled capital account liberalization as proposed, implement flexible exchange rate policies: This means to reduce the pressure on the Government taking foreign exchange reserves for an intervention in the market now that forex reserves could provide a cushion that guarantees the financial security of a nation during its integration processes. 
- In long terms, when the financial development has reached the required threshold, maintain its stability, exclusively with financial depth serving as a principle focus; in terms of institutional quality, a rising issue lies in a call for the commitments to openness after WTO accession. The process shall start from a few aspects closest to the thresholds in need, such as political stability, government effectiveness, rule of law, control of corruption, regulatory quality, and last but not least, voice and accountability. Among these a special attention should be directed to the issues of development supports and financial market monitoring

\section{Notes}

${ }^{1}$ Coefficient of marginal effects of financial openness on growth in the FE estimates is -0,0207 『PC \^2+0,0484PC-0,0235. Upper/lower thresholds result from solving the equations in which coefficient of marginal effects equals zero.

${ }^{2}$ Upper threshold is derived from quadratic interactions. We tested the financial openness interaction with higher order polynomials of the threshold variable. The coefficients in higher order interactions are often not statistically significant and very small in magnitudes.

\section{References}

Acemoglu, D., Johnson, S., Robinson, J. A., \& Thaicharoen, Y. (2003). Institutional causes, macroeconomic symptoms: Volatility, crises, and growth. Journal of Monetary Economics, 50(1), 49-123.

Aghion, P., \& Banerjee, A. (2005). Volatility and growth: Clarendon lectures in economics. Oxford: Oxford University Press.

Aghion, P., Bacchetta, P., Rancière, R., \& Rogoff, R. (2009). Exchange rate volatility and productivity growth: The role offinancial development. Journal of Monetary Economics, 56(4), 494-513.

Arellano, M., \& Bond, S. (1991). Some tests of specification for panel data: Monte Carlo evidence and an application to employment equations. Review of Economic Studies, 58, 277-297.

Bekaert, G., Harvey, C. R., \& Lundblad, C. (2005). Does financial liberalization spur growth? Journal of Financial Economics, 77(1), 3-55.

Blundell, R., \& Bond, S. (1998). Initial conditions and moment restrictions in dynamic panel data models. Journal of Econometrics, 87, 115-143.

Calvo, G., Izquierdo, A., \& Mejia, L.-F. (2004). On the empirics of sudden stops: The relevance of balance-sheet effects (Federal Reserve Bank of San Francisco Proceedings).

Chanda, A. (2005). The influence of capital controls on long run growth: Where and how much? Journal of Development Economics, 77(2), 441-466. 
Chang, R., Kaltani, L., \& Loayza, N. V. (2009). Openness can be good for growth: The role of policy complementarities. Journal of Development Economics, 90(1), 33-49.

Chinn, M. D., \& Ito, H. (2008). A new measure of financial openness. Journal of Comparative Policy Analysis, 10(3), 309-322.

Frankel, J., \& Cavallo, E. A. (2008). Does openness to trade make countries more vulnerable to sudden stops or less? Using gravity to establish causality. Journal of International Money and Finance, 27, 1430-1452.

Klein, M. W. (2005). Capital account liberalization, institutional quality, and economic growth: Theory and evidence (Working Paper No. 11112). Cambridge, MA: NBER.

Kose, M. A., Prasad, E. S., Rogoff, K., \& Wei, S.-J. (2009). Financial globalization: A reappraisal. IMF Staff Papers, 56(1), 8-62.

Kose, M. A., Prasad, E. S., \& Taylor, A. D., (2011). Thresholds in the process of international financial integration. Journal of International Money and Finance, 30(1), 147-179.

Kraay, A. (1998). In search of the macroeconomic effects of capital account liberalization. (Unpublished). Washington, D.C: The World Bank Group.

Lane, P. R., \& Milesi-Ferretti, G. M., (2007). The external wealth of nations Mark II: Revised and extended estimates of foreign assets and liabilities, 1970-2004. Journal of International Economics, 73(2), 223-250.

Mishkin, F. S. (2006). The next great globalization: How disadvantaged nations can harness their financial systems to get rich. Princeton, NJ: Princeton University Press.

Obstfeld, M., \& Rogoff, K. (1995). The mirage of fixed exchange rates. Journal of Economic Perspectives, 9(4), 73-96.

Quinn, D. P., \& Toyoda, A. M. (2008). Does capital account liberalization lead to growth? Review of financial studies, 21(3), 1403-1449.

Roodman, D. (2006). How to do xtabond2: An introduction to "Difference" and "System" GMM in Stata (Working Paper No. 103). Washington, DC: Center for Global Development.

Wei, S.-J. (2001). Domestic crony capitalism and international fickle capital: Is there a connection? International Finance, 4(1), 15-46. 